\title{
5. 日中の眠気の鑑別診断
}

\author{
内山 真 ${ }^{1)}$ 、亀井雄一 ${ }^{2)}$ \\ 国立精神・神経センター精神保健研究所 精神生理部 ${ }^{1)}$ \\ 国立精神・神経センター国府台病院 精神科 ${ }^{2)}$
}

一般に産業現場においては、日中の眠気が問題となった場合、やる気のなさ、志気や動機づけの低さ などと関連づけられやすい。しかし、なかには過眠症などの睡眠障害に基づくものがあるため、適切な 診断と治療が必要になる。ここでは、日中の眠気の原因から、夜間睡眠の量的不足によるもの、夜間睡 眠の質的低下によるもの、体内時計のリズムの異常によるもの、覚醒維持機能の低下に基づくものに分 け、それぞれの特徴と鑑別診断について述べる。

\section{1 、夜間睡眠の量的不足による日中の眠気 : 睡眠不足症候群}

いくら眠っても眠り足りない、何時間も眠っている、日中に眠気が強いという状態の背景には、慢性 的睡眠不足が続いていることがある。患者本人がこの慢性的睡眠不足に気づいていない場合があり注意 が必要である。

現代の社会生活は夜型化する傾向にあり、睡眠時間も短縮している。通勤や通学に時間がかかるため、 入眠時刻が遅いにもかかわらず、朝早く起床することになり、実質的睡眠時間は生理的に必要な時間を はるかに下回る場合が出てくる。このような短時間の睡眠習慣が慢性的に続くため、日中の強い眠気と ともに倦急感、易疲労感、頭重感などさまざまな心身の症状が出現する場合がある。こうした状態を睡 眠不足症候群と呼ぶ。診断のためには日常生活における睡眠習慣を評価することが重要である。また、 休日の睡眠時間が極端に長くなってないかを問診し、平日に比べて休日の睡眠時間が長く、長期休睱の 期間に十分睡眠をとった場合は日中の眠気や身体症状が改善する場合は、この睡眠不足症候群が疑われ る。

睡眠不足が疑われた場合は、十分な睡眠をとらせることである。1日や 2 日では解消されない場合が 多いため、2 週間ほどはきちんととらせる必要がある。

\section{2. 夜間睡眠の質的低下による日中の眠気}

夜間睡眠の量的不足がないにもかかわらず、日中の眠気が強い場合は夜間睡眠の質的低下を疑う。日 中の眠気をきたす睡眠障害としては、睡眠中の換気停止により睡眠の質的低下をもたらす睡眠時無呼吸 症候群、睡眠中の不随意運動により睡眠の質的低下をもたらす周期性四肢運動障害などがある。 睡眠時無呼吸症候群では、睡眠中に上気道の閉塞あるいは狭小化が起こり、10 秒以上続く無呼吸が繰 り返し起こる。血中酸素分圧の低下による呼吸の再開時に覚醒反応がおこり、このために睡眠が分断さ れ、夜間の不眠や日中の過眠が生じる。気道の家族から、いびきをかいていないか、睡眠中に呼吸が停 止していないかを確かめる。起床時に頭痛や口渴がみられることが多い。日中に居眠りをすることが多 くなるが、眠ったからといってリフレッシュすることは少ない。顎が小さい、いの首、肥満、中年男性、 飲酒などがリスクファクターとなる。高血圧や心疾患などの増悪因子となるので専門的治療が必要であ る。

周期性四肢運動障害では、眠りにはいると下肢を中心に不随意運動が繰り返し出現する。この不随意 
運動の出現により睡眠が浅くなり、時に覚醒することになり、睡眠の質が全般的に低下する。中途覚醒 を訴えることが多いが、日中の眠気を主訴に受診することもある。患者がこうした睡眠中の不随意運動 を自覚していないことが多いため、睡眠中の下肢の動きに関する家族の観察が必要となる。最終的に終 夜睡眠ポリグラフ検查で確定診断し、不随意運動に対する楽物療法を行う。

\section{3. 体内時計のリズムの異常による日中の眠気：概日リズム睡眠障害}

概日リズム睡眠障害では、体内時計のリズムが昼夜の変化とずれることによって不眠や過眠が出現す る。時差症候群がある。短時間で時差のある地域を移動するために、現地の昼夜りスムと出発地に同調 している体内時計のリズムが合わない状態となる。到着地における昼であっても、発地に同調している 体内時計のリズムが夜の状態であると強い眠気が出現すると同時に、夜には不眠となる。

体内時計のリスムが極端な遅れが戻せないため朝型まで入眠できず、いったん眠ると昼過ぎまで起き られない睡眠相後退症候群では、無理して起床すると、生体リスムが昼にならない時間帯では強い眠気 やだるさが出現する。非 24 時間睡眠・覚醒症候群は、生体りズムが毎日約 1 時間ずつずれていく。そ のため、入眠時刻および覚醒時刻が毎日遅れていく。社会生活に適応しょうと無理に起きても、昼間に 睡眠時間帯があたった時期には過眠をきたし、夜に睡眠時間帯が来た時期には日中の過眠がなくなると いうパターンを示す。

\section{4. 覚醒維持機能の低下に基づく日中の眠気}

覚醒維持機能の低下に基づく日中の眠気を示す疾患としては、ナルコレプシーや特発性過眠症がある。 これらに対しては、最終的に終夜睡眠ポリグラフ検査で確定診断し、精神刺激薬による薬物療法を行う。

日中に発作的な眠気におそわれて眠ってしまうが、数分から数十分眠ると眠気がすっきりととれるよ うな過眠が、ナルコレプシーにおける日中の眠気の特徵である。これは、前夜の睡眠時間にかかわらず、 ほぼ毎日出現する。入学試験や商談中など通常なら居眠りすることが考えられないような場面で眠って しまう。ナルコレプシーの大きな特徵は、睡眠発作とともに、情動脱力発作（カタプレキシー）と呼ば れる症状が認められることである。これは、笑い、鷩愕などの情動の変化により突然筋緊張の低下ない しは消失が引き起こされ、全身の力が抜けて座り込んでしまう。ナルコレプシーのほかの特徴として、 睡眠麻㽻と入眠時幻賞がある。

特発性過眠症では、夜間睡眠が十分であるのに、過度の眠気が続く。眠気の強さはナルコレプシー程で はなく、どうしても居眠りしてはならない状況下では居眠りを我慢できる場合もある。居眠りの時間、 夜間睡眠ともに長いことが多い。睡眠からの目賞めが悪く、睡眠酩醇を呈することもある。睡眠の後の リフレッシュ感も得られ難いなどが特徵である。

日中の眠気について、頻度の高い疾患についてその原因から分類し、臨床特徵を述べた。の他にも、 うつ病により眠気が出現する場合や身体疾患治療楽や抗不安薬が日中の眠気の原因となっていること もある。産業現場において、日中の眠気が問題になった場合には、やる気のなさや急けなどと決めつけ ることなく、眠気の性質や夜間睡眠の特徵、随伴症状に留意し、適切な医学的診断を行うことが重要で ある。 